\title{
ARTICLE
}

\section{Warlords, the United States, and the state of anarchy in Afghanistan}

\author{
AHMAD SHAH AZAMI ${ }^{* 1}$ \\ ${ }^{*}$ Department of International Relations and European Studies, Faculty of Social Studies, Masaryk University \\ in Brno, Czech Republic
}

\begin{abstract}
As part of its "War on Terror", the United States (US) provided immense sums of money and advanced equipment to Afghan warlords in order to defeat and dismantle the Taliban and al-Qaeda in Afghanistan. Nearly two decades after the 2001 US-led intervention in Afghanistan that toppled the Taliban regime, the US continues supporting the warlords in various ways. As the intervention was also aimed at establishing a functioning state and reconstruction of the war-torn country, the US needed the support of local warlords to achieve its goals. However, over time, warlords and warlordism became a major challenge to the postTaliban state-building project and in many ways undermined the overall security and the state monopoly on violence. These warlords, who had been mostly expelled and defeated by the Taliban regime, returned under the aegis of the B52 bombers, recaptured parts of the country and reestablished their fiefdoms with US support and resources. They not only resist giving up the power and prestige they have accumulated over the past few years, but also hamper the effort to improve governance and enact necessary reforms in the country. In addition, many of them run their private militias and have been accused of serious human rights abuses as well as drug trafficking, arms smuggling, illegal mining and extortion in the areas under their control or influence. In many ways, they challenge the government authority and have become a major hurdle to the country's emerging from lawlessness and anarchy. This paper explores the emergence and reemergence of warlords in Afghanistan as well as the evolution of chaos and anarchy in the country, especially after the US-led intervention of late 2001. It also analyzes the impact of the post-9/11 US support to Afghan warlords and its negative consequences for the overall stability and the US-led state-building process in Afghanistan.
\end{abstract}

\section{Keywords}

Warlords, anarchy, state building, security, United States, Afghanistan, war on terror, terrorism

DOI: https://doi.org/10.24132/cejop_2021_1

How to cite: Azami, A.S. 2021. "Warlords, the United States, and the state of anarchy in Afghanistan." Central European Journal of Politics 7 (1): 46-75. DOI: 10.24132/cejop_2021_1

\footnotetext{
${ }^{1}$ Address: Mgr. Ahmad Shah Azami, PhD candidate, Department of International Relations and European Politics, Faculty of Social Studies, Masaryk University, Joštova 10, 60200 Brno, Czech Republic, E-mail: ahmad.s.azami@gmail.com
} 


\section{Introduction}

Following the fall of the Taliban regime in Afghanistan in 2001, the United States (US) spent a lot of blood and treasure in the country helping to build state institutions and critical infrastructure. However, along the ways, the US policy makers also made a number of mistakes, which undermined its own stated mission and goals. At many occasions, it invested in the wrong people and the wrong projects. Many prominent warlords had been among the most privileged US partners in Afghanistan. The US military and financial assistance to warlords in Afghanistan paved way for chaos and anarchy in the country.

The research question I present here explores what was the outcome of the US continuous support to Afghan warlords in Afghanistan? Along with the emergence and reemergence of warlords in the country, the paper investigates the impact of the US support to Afghan warlords after $9 / 11$ and its negative consequences for overall stability and the US-led state building process in Afghanistan.

This is a phenomenological research study and this qualitative research method is used to describe how the Afghans experienced the phenomenon of US support to warlords in Afghanistan. Since the phenomenology is solely concerned with the study of experience from the perspective of participants, therefore, the methodology does not include a hypothesis or any preconceived ideas about the data collected. Phenomenological research is "based on the assumption that there is an essence or essences to shared experience. These essences are the core meanings mutually understood through a phenomenon commonly experienced." (Patton 2002: 106) I have explored the perceptions, perspectives, understandings, and feelings of Afghans who experienced or lived the phenomenon. I have used the hermeneutic phenomenology that is focused on subjective experience of individuals and groups.

The research is primarily conducted through in-depth interviews, conversations, focus group meetings and participant observation. Interview questions were open ended or less structured which were more effective in order to maximize the depth of the information collected. While asking the participants for their lived experiences, various types of interview methods such as face-to-face, audio, and telephonic interviews were conducted. Interviews were conducted with current and former Afghan parliamentarians and officials, politicians, tribal elders, activists, and experts, etc. Using quota-sampling method, interviews with several other people residing in different parts of Afghanistan and belonging to various spheres of life have been conducted.

As secondary sources, scientific papers, special reports and findings, newspapers, and books relevant to the research question have been used to support the argument how the continuous support to Afghan warlords paved way for chaos and anarchy in Afghanistan. After collection and compilation of data, I used the method of 'explication' that implies to the investigation of the constituents of a phenomenon while keeping the context of the whole through granting each perception an equal value. 


\section{Theoretical framework}

Warlords in Afghanistan are mostly considered as existential threat to the post-9/11 modern state. They have gained power and influence in the anarchic conditions which make the state weak and vulnerable. "Warlords profit from political economies grounded in violent criminality and exploit and perpetuate uncertainty and insecurity" (Mukhopadhyay 2014: 5).

Warlordism has gained a well-considerable position in international relations and politics as well as in the theories of modern warfare. Some authors have termed the warlord conflict 'wars of the third kind' in the 20th century. Coming in the wake of 'institutionalized warfare' of the 18th and 19th centuries, and 'total warfare' in the first half of the 20th century, 'wars of the third kind' are characterized by an absence of fixed territorial boundaries, elaborate institutionalized military rituals, major fronts and military campaigns (Holsti 1996: 34).

"Warlordism is a product of the fracturing of sovereign state structures and reflects the uneven integration of regimes, especially those in the developing world". (Rich 1999: 1) The growth in warlordism in contemporary international polities has tended to undermine some of the dominant assumptions behind the notion of 'praetorianism' in Western social science. 'Praetorianism' refers to the intervention of the military into politics and the breakdown of civil-military relations (Rich 1999: 2).

"Resources, legitimacy and support, and the state weakness are some of the core components of the warlord system." (Ginty 2010: 583) Afghan warlords are land mafia, smugglers, extortionists, and crooks on one hand, they exploit the mineral rich and levy the taxes and duties on the other hand. They borrow their legitimacy and support from long term exploitation of ethnicity, tribalism, sect and locality. They flourish well in a fragile state and can strengthen themselves when the central government is ineffective and weak.

Warlordism creates a state of anarchy when the government is either weak or there is chaos and disorder, while anarchy paves way for warlordism to flourish. Anarchy is an ancient concept of international relations theory that portrays the absence of ruler or central authority. It indicates a world in chaos, disorder, or conflict.

Anarchy has become a toxic concept in IR theory, routinely associated with conservative and retrograde politics ... On the first account, anarchy is a priori, pre-social condition of lawlessness from which political community evolves. On the latter, anarchy is the product of a set of assumptions about the utility maximizing proclivities of individuals in a condition of material scarcity. In both, it is pathological but productive because of this. (Havercroft and Prichard 2017: 254) 
In Neorealism theory, the world is anarchic and there are wars. This theory adds that states are selfish and rational and seek relative gains. A neorealist, Kenneth Waltz, in his book "Theory of international politics" writes that anarchy is taken to mean not just the absence of government but also the presence of disorder and chaos (Waltz 1979: 114). He explains, the more influential the agency, the stronger the desire to control it becomes. In contrast, units in an anarchic order act for their own sakes and not for the sake of preserving an organization and furthering their fortune within it. Force is used for one's own interest (Waltz 1979: 112).

On the other hand, Thomas Hobbes imagines politics in a pre-social state of nature (Hobbes 1894: 58). The result is an unusually clear theory that gives roughly equal weight to human nature and international anarchy. "Hobbes makes three simple assumptions: Men are equal; They interact in anarchy; They are motivated by competition, diffidence, and glory." (Burchil et al. 2009: 33-34) In a Hobbesian environment, the fact that a local ruler might be killing, looting and raping in the neighboring villages is not necessarily seen as a problem by the inhabitants of a village that benefits from the protection of that ruler. Moreover, "a significant part of the population might actually benefit in other ways from the activities of the warlord, for example by participating in the looting." (Giustozzi 2005: 12)

Antonio Giustozzi writes that in the Hobbesian world of war-torn Afghanistan, warlords are "service providers" to a much larger "military class" of petty local military commanders. "The most powerful, influential, and charismatic leaders even develop "networks of networks" becoming national players and formulating alliances with political actors struggling for the control in Kabul." (Giustozzi 2010)

In the case of Afghanistan, warlords were the former anti-Soviet Mujahideen commanders who had private militias and control or influence over a specific territory where they imposed and collected taxes. They were not abiding by the law; they challenged the writ of central government instead.

"Warlords today flout and undermine state capacity and state institutions, and they do so by colluding with cost-conscious, corrupt, or frightened officials and bureaucrats. In other words, warlords are parasitic creatures of the state". (Marten 2012: 3) They usually rule with the barrel of a gun and talk the language of bullets rather than depending on ballots, however, many warlords have paved way for the parliament and other government offices in post-9/11 Afghanistan in order to maintain their power.

\section{Warlords and warlordism}

Warlord or warlordism is a subjective matter, however, there is a plentiful agreement among scholars on how to define the term. Warlords are those "actors who are able to make decisions without necessarily being controlled by institutional bodies of state or society. They control the means of physical force-private as well as state owned-and 
have the potential and capacity to decide about its use" (Schetter, Glassner, and Karokhail 2007: 140). They control and support a specific piece of land through power. "They are "lords" (essentially, feudal landlords) who threaten or use "war" (violence unleashed by their militias) to retain their power." (Marten 2012: 3)

A Warlord is an armed leader who governs a territory without any central government. He has full and autonomous control over a military force, which he can use at will; he exercises political power over part of the territory of a state, where central authority has either collapsed or has weakened; he uses violence to maintain his power; he displays a neopatrimonialist attitude towards the polity that he is running, where therefore institutionalization is weak or absent; he is only or primarily concerned with his own benefit and does not fight for a superior cause, although he might claim to represent regional or sectarian interests; as a result, he lacks interest in changing the nature of the state that he is trying to overthrow or that has already been overthrown, and indeed his leadership role is not dependent on eventually seizing state power (Giustozzi 2005: 14).

The etymology of the term "warlord" seems to have started as a translation of "Kriegsherr", a term used to indicate German war leaders and, later, a title attributed to emperors (Giustozzi 2005: 1). Antonio Giustozzi is of the view that the term "warlord" first found widespread academic use among sinologists to indicate the military rulers who abounded in China during the republic period (1912-1949). "In the 1980s, mediaeval historians started applying the term to the history of Europe and Japan. During the 1990s, historians of antiquity also started using the term to indicate a blurred category of local rulers who entertained an ambiguous relationship with the central government towards the end of the Roman Empire." (Giustozzi 2005: 1)

However, some other scholars trace back the history of warlordism to fourth and fifth century B.C. in ancient Greece as well as in the Achaemenid Empire where there were certain people and commanders who presumed some degree of disorder or endeavored to gain control of certain areas and population (Castro 2017: 56; Gonzalez 2017: 89; Tuplin 2017: 17). "Succession and secession crises, structural sources of disorder, and sedition satraps are worth mentioning in this regard." (Tuplin 2017: 22-26)

Warlord is a useful term when applied to historical contexts when control of the State is significantly weakened, for example: the emergence, from the Archaic period of known mercenary leaders in Classical Greece, along with aspects of piracy and organized banditry witnessed throughout the Mediterranean (Zimmermann 2010: 28-29).

State leaders often choose to cooperate with warlords in order to avoid the chaos that they could otherwise unleash, in hopes of avoiding warfare or anarchy in areas that would otherwise be difficult to govern. The absence of immediate warfare and anarchy, however, does not necessarily create long-term security. Bargains with warlords are associated with glaring economic underdevelopment and corruption, and they make 
"state-failure" an enduring outcome (Marten 2012: 7-8). "Individual warlords and leaders of weak states instead coexist in an uneasy symbiosis, making warlords state parasites and state-drainers, not state-builders" (Marten 2012: 28).

\section{Emergence of warlords in Afghanistan}

Afghanistan has been facing the phenomenon of warlordism for the last 40 years, which has both directly and indirectly affected the lives of nearly all of its citizens. Although there were high hopes that the post-9/11 US-led state building efforts and the process of democratization will end up eliminating this phenomenon or at least weaken the warlords' grip on power, warlords still possess considerable influence and play an effective role in almost all aspects of the country including politics, governance and security.

Afghan warlords are the transformation of the mujahideen, alias freedom fighters, who resisted the Soviet occupation of the country from 1979-1989. The United States and its international allies as well as most Muslim countries prominently Saudi Arabia financially and militarily supported the Afghan mujahideen against the Communist Soviet Union. By the time Soviet forces retreated from Afghanistan in 1989, the Kabul government's control had been substantially limited. On the other hand, several group and sub-group commanders of the mujahideen had adequate weapons and gathered fighters to control a specific area or locality of the country.

In 1992, three years after the Soviet withdrawal, the Soviet backed regime in Kabul collapsed and a civil war broke out among various mujahideen factions in Kabul for the control of the State. As the State collapsed, a number of mujahideen commanders in the provinces established their own little fiefdoms and built checkpoints in their localities to collect revenues and customs from the public. In a state of lawlessness and anarchy, the widespread intimation of local population started resulting in serious human rights abuses including theft, abductions and murder. The mujahideen commander-turned warlords had their own private militia and controlled a specific territory of the country or even parts of the cities.

During this period of anarchy and lawlessness, a new force known as the Taliban Movement (a group of young students schooled in the Pakistani madrassas or religious seminaries) emerged in 1994. Pakistan supported the Taliban who expanded their territorial control with an astonishing speed (Zakaria 2015). A large number of ordinary Afghans initially welcomed the Taliban who got rid of warlords and brought peace and normalcy to their lives. The Taliban captured the capital Kabul in 1996 and eventually controlled almost 90\% of Afghanistan (BBC 2016). A number of mujahideen-turned warlords who resisted the Taliban were either killed or forced to leave the country. Many of these commanders escaped to the north of Afghanistan where there were still pockets outside the Taliban's control and started fighting against the Taliban. 
Taliban introduced and executed punishments based on their interpretation of Islam. They were also accused of providing a sanctuary to Osama bin Laden and other alQaeda leaders who were blamed for the attacks on the World Trade Center and the Pentagon on 11 September 2001. On 7 October 2001, a US-led military coalition invaded Afghanistan and by the first week of December, the Taliban regime had collapsed. Many senior Taliban leaders took refuge in Pakistan, from where they reorganized themselves to fight the US-led coalition and Afghan security forces in Afghanistan (BBC 2016).

\section{US support to Afghan warlords}

The US supplied large amount of money and weapons to the former Afghan mujahideen who were turned warlords in post-9/11 scenario. This act of generosity done by the US was as part of its war against Taliban and al-Qaeda in Afghanistan. "The US assistance to Afghan warlords continued after the fall of the Taliban regime and dismantling of the alQaeda network in Afghanistan." (Azami 2020: 6) While, the support of the warlords helped the Washington and its allies in getting rid of the Taliban and al-Qaeda, they also threatened the newly born democracy and state-building process in the war-torn country. As most of these warlords had been defeated or expelled by the Taliban, the arrival of the US and fall of the Taliban regime meant they were back in power.

The anti-Taliban coalition of Afghan warlords or commanders was commonly known as the Northern Alliance (NA) due to its location and operation in the north of the country. NA's best-defended enclave was in the country's north-eastern corner. Ahmad Shah Massoud, the Tajik commander from Panjshir, was the most powerful of the NA leader commanders followed by the ethnic Uzbek, Abdul Rashid Dostum. Dostum's forces and those of his erstwhile rival and sometimes ally, Atta Muhammad Noor, held a string of strategic ridges and valleys south of the crossroads town of Mazar-e Sharif. None of these warlords was a choirboy when it came to human rights, but they had experienced troops to fight against the Taliban (Franks 2004: 297).

General Tommy Franks, the then Commander-in-Chief of the United States Central Command (CENTCOM) writes in his book, American Soldier, that NA commanders hated the Taliban and the Araban (their derisive term for al-Qaeda, which, among Arabs, included large numbers of Chechens and Pakistanis). They were more than eager to work with the Americans. General Franks states:

Our plan hinged on combining these tough, highly motivated opposition fighters with the Coalition's massive air power. To do so, however, we had to have a Special Forces teamOperational Detachments Alpha (ODA) - with each of the local Northern Alliance commanders. And that was where we were stuck. An advance CIA team, code name Jawbreaker, was with Fahim, but other Agency officers had yet to link up with Dostum, 
Noor, and their subordinates. Although we were establishing communications with the disparate Northern Alliance leaders, we'd yet to place any Agency officers physically with them to pave the way for our Special Forces. (Franks 2004: 297)

After Massoud's death on 9 September 2011, the NA leadership devolved on four tough, mutually suspicious commanders. Muhammad Fahim Khan, second by Bismillah Khan Mohammadi, headed the eastern Tajiks. Ismail Khan in the west commanded a second Tajik contingent. Abdul Rashid Dostum led the Uzbeks. Karim Khalili ran the Hazara element. Together, they mustered around 20,000 fighters with AK-47 rifles, Russiandesigned PKM machine guns, mortars, rocket launchers, Toyota pickups tricked out with machine guns, and a few dozens creaky tanks and armored personnel carriers. They even had few old Russian Mi-8 helicopters (Bolger 2014: 41-42).

Operation Enduring Freedom (OEF), the official name given by the US government to its global War on Terrorism in Afghanistan, began on 7 October, 2011, when the US President George W. Bush announced that the US and British forces had begun airstrikes on Taliban and al Qaeda targets in Afghanistan. The war began with nighttime air strikes against preplanned targets such as Taliban airfields and headquarters facilities. General Franks writes that ahead of the Operation Enduring Freedom (OEF), the US involved inserting advance teams of CIA officers wielding satellite phones and sacks of hundreddollar bills into Afghanistan to begin bolstering the fractured NA and other tribals in the anti-Taliban opposition.

Here, too, we were making strides. Already Agency officers had made contact with the principal warlords. Generals Muhammed Fahim Khan-the Tajik successor to the murdered Ahmad Shah Massoud - and Abdul Rashid Dostum - the Uzbek militia leader based farther west -- were counting their initial support money, and preparing to accept CIA paramilitary operators from the Agency's Special Activities Division. Dostum's longtime friends-and rivals-Atta Muhammad Noor and Mohammed Mohahqeq, a Shia Muslim Hazara, were standing by to receive their Agency liaison officers as well. These officers would lay the groundwork for our Special Forces Teams, which would follow almost immediately. Known as "A-Teams" for years, these twelve-man units now went under the acronym ODA-Operational Detachment Alpha, some of the toughest and besttrained soldiers in the American military. (Franks 2004: 267)

Ahead of the Operation Enduring Freedom (OEF), on 27 September 2001, a CIA officer named Gary led ten paramilitary officers into Afghanistan in a Russian-made Mi-17 helicopter owned by the CIA. Ronald Kessler writes in his book "The CIA at War: Inside the Secret Campaign Against Terror" that Gary had spent 20 years in Kabul, Tehran, Islamabad and Dubai. After 32 years with the agency, he was just about to retire when 
Cofer Black asked him to stay on and lead a paramilitary team code-named "Jawbreaker". Gary who could speak Pashto and Dari, the two principle languages of Afghanistan, took with him $\$ 3$ million in nonsequential $\$ 100$ bills that he carried in a large steel suitcase. Along with case officers who spoke Pashto and other local languages, Gary met with NA leaders already recruited by the agency. He would place bundles of cash in front of them and ask for their help in preparing the way for US Special Forces. He wanted the positions of enemy forces and intelligence on their communications, arms, and structure. Village elders could be bought for $\$ 5,000$; warlords could be bought for $\$ 50,000$ to $\$ 100,000$ (Kessler 2003: 237).

The US plan was to rely on air power and surgical strikes, supported on the ground by Special Operations Forces (SOF), who would work alongside the NA commanders to identify and validate targets for allied aircrews. By mid-November 2001, NA forces were closing in on Kabul. The Bush administration was now divided on whether the NA should move on and enter Kabul or not (Khalilzad 2016: 116).

The US Secretary of State Colin Powell proposed two options: either the US should turn the capital over to the UN or the Organization of Islamic Conference (OIC) peacekeepers; or it should fine-tune the war strategy such that the NA and the empowered Pashtun forces would liberate the city jointly. Militia commanders had looted the city when they entered the Kabul in 1992, and Powell feared that the NA occupation of the capital would alienate Pashtun opposition forces. The US Vice President Dick Cheney and Secretary of Defense Donald Rumsfeld pushed back against the idea of restraining the NA. They wanted to deliver a quick and devastating blow to al-Qaeda in Afghanistan, overthrow the Taliban regime, and send a message of resolve to other state sponsors of terrorism around the world (Khalilzad 2016: 90).

Major General Dawlat Waziri, the former spokesperson of Afghanistan's ministry of defense (who retired in 2018) says the US thought that warlords wouldn't create problems after they enter the capital city of Kabul. However, he believes this was a wrong assumption as there had been a civil war for many years in Afghanistan and that everyone wanted the control of the capital city. He adds "although the US didn't stop warlords to enter Kabul right after the fall of the Taliban, it had the option to stop and curtail their influence later which it didn't." (Waziri 2018)

By 7 December 2001, it was almost all over. The Taliban had abandoned Kandahar, their last stronghold, where the CIA had helped create a force of 3,000 local fighters, mostly loyal to former mujahideen-turned warlords. The CIA had spent $\$ 70$ million on getting the NA commanders and a number of tribal elders to promote the Agency's goals. Much of the money went for equipment, light weapons, four-wheel-drive vehicles, and communication devices like satellite phones (Kessler 2003: 238-239). 
Meanwhile, the UN convened a conference in Bonn, Germany, from 27 November to 5 December 2001 on the future of Afghanistan. Four Afghan groups were invited to the Bonn Conference. The Northern Alliance had 11 representatives composed of mostly ethnic Tajiks, Uzbeks, Hazaras and a very few Pashtuns. The Rome Group had also 11 representatives who were loyal to the former King of Afghanistan, Muhammad Zahir Shah, who had been living in exile in Rome but didn't attend the conference personally. The Peshawar Group had five representatives who were ethnic Pashtuns living in exile in Pakistan. The Cyprus Group had also five representatives who were Iran-backed exiled Afghans. The Taliban and Hizb-e-Islami (Islamic Party), led by the former mujahideen leader, Gulbuddin Hekmatyar, were not invited to the conference. The decision was made in the conference that 16 of the 29 ministries in the interim government would be in the NA hands while Hamid Karzai (who was considered to be a member of the Rome Group and who didn't attend the conference personally) would preside as head of the interim government. The NA did retain control over the ministries of Defense, Interior, and Foreign Affairs among others (Khalilzad 2016: 127).

Rather than sidelining the warlords and restoring the power and authority of the state, the Bonn Agreement of 2001 sought to accommodate them instead. The Agreement missed an unprecedented opportunity to emasculate Afghanistan's warlords. "One of the most obvious effects of the reconstitution of warlord power has been the emergence of competition over territory and resources, competition which has often degenerated into violence." (Hodes and Sedra 2007: 12-13)

"In Afghanistan, warlords were able to profit from the limited peace of the postTaliban state-building project. Many of the warlords were compelled to change and reach new forms of accommodation with the nascent state. Their warlordism may have been diluted, but there was no instant transformation into model citizen." (Ginty 2010: 585)

Peceny and Bosin write that it was expected that the economic reconstruction and democratization would facilitate political and social change that in the end would undermine the pillars of Afghan warlordism. "This has not happened, however. Instead, the US helped sustain a warlord system that undermined the long-term modernization strategy it preferred." (Peceny and Bosin 2011: 613)

The US agencies, particularly those in the military and intelligence communities, relied on these warlords for different reasons, including historical relationships, intelligence, information, political needs in Kabul or provinces, and as security force multipliers or force protectors. Their association with the United States empowered them and provided access to lucrative contracts related to the reconstruction effort, provision of logistics and military presence. They also used these money and access to get elected to provincial and national legislature gaining more power and impunity. "The US partnership and association with such individuals gave the Afghan population the impression the US tolerated corruption and other abuses, seriously undercutting US credibility and democracy in Afghanistan." (SIGAR 2016) 
Warlords wanted the new Afghan security forces to be composed of their militias. "The unwillingness of either the US or Europeans to exert much military pressure against the warlords and faction leaders, however, meant that their agreement to the building of depoliticized armed forces had to be obtained largely through incentives, mainly through the offer of political incorporation." (Rubin 2006a: 180)

Hamid Karzai was sworn in as the head of the interim Afghan administration on 22 December 2001 while he was elected as President for two years transitional set up by the traditional Loya Jirga (grand council) in Kabul on 13 June 2002. Later, he won the race in the first direct presidential elections in October 2004 and was elected for the term of five years according the new Afghan constitution, which was promulgated in January 2004.

In his first nationwide radio address on 10, January 2002, Karzai spoke of the need to disarm the warlords. In reply, the warlords spurned him by saying that if the Americans had armed them, who was Karzai to tell them to disarm? The next month, Dr. Abdul Rehman, 49, the jovial minister for tourism and civil aviation, had been stabbed to death on the tarmac of Kabul international airport by rival warlords in February 2002 (Rashid 2008: 179).

Warlordism was perhaps the most persistent challenge of this period. As Zalmay Khalilzad (former US envoy and ambassador to Afghanistan) writes, on a number of occasions, Karzai vented with great emotion about the threat.

Karzai worried that as people tired of insecurity or oppression by their local strongmen, they might again welcome the Taliban or others who promised them justice and peace... The difficulty was that the United States was working with the warlords. The warlords had carried the burden of the ground campaign against the Taliban and al-Qaeda and, in the absence of anything like an effective national army, were still needed to take on the insurgents. (Khalilzad 2016: 136-137)

Then in Spring 2002, "Pacha Khan Zadran, a warlord in Afghanistan's eastern Paktia province had threatened Karzai to launch a civil war if he would not be recognized as the provincial governor by the Karzai administration." (Azami 2020: 7) Karzai was hopeful of the US support to curb the militia commanders or warlords who challenge the central administration. It was the first-ever direct threat from a militia commander to the Karzai's new administration in Post-Taliban Afghanistan. Karzai didn't want to set a precedent for others by fulfilling the illegitimate demands of Zadran. On 30 April, Karzai issued an ultimatum to Zadran to surrender or face the consequences.

However, the US Department of Defense was apparently not ready to support Karzai against an Afghan warlord. The US Secretary of Defense Donald Rumsfeld sent a memo to President Bush and wrote that if Karzai could not prevail against local forces 
without American military assistance, he could not survive politically anyway. According to Rumsfeld:

I was convinced Karzai needed to learn to govern the Chicago way. In the 1960s, Mayor Richard J. Daley ruled Chicago - a city of many diverse and powerful elements- using maneuver, guile, money, patronage, and services to keep the city's fractious leaders from rebelling against his authority. President Bush agreed with my recommendation, and I told Karzai he would have to resolve the dispute without the promise of rescue by the American military. (Rumsfeld 2011: 376)

Rumsfeld's determination to legalize warlord authority against the wishes of the Afghan government and people was the most fatal mistake he was to make. Karzai considered Rumsfeld's statement an insult to all Afghans, and from that time on, he saw the secretary of defense as being completely out of touch with reality. As the war wound down, the Bush administration was faced with two policy choices. It was clear by the summer of 2002 that the warlords were becoming stronger while the Karzai regime lacked the resources to compete. The unstated US strategy was to leave Karzai ineffectual in the capital, protected by foreign forces, while relying on the warlords to keep Pax Americana in the countryside and the US Special Operation Forces (SOF) to hunt down al Qaeda. It was a minimalist, military intelligence-driven strategy that ignored nation building, creating state institutions, or rebuilding the country's shattered infrastructure. By following such a strategy, the United States left everything in place from the Taliban era except for the fact of regime change (Rashid 2008: 181-183).

It gave the Taliban just the propaganda excuse they needed to reorganize themselves and launch an insurgency against the Afghan government and its international allies. In March 2002, disgruntled aid officials at the American embassy said that the CIA's one billion US dollar budget was being used to pay off warlords and their militias, carry out quick-impact development projects, find al Qaeda leaders, and conduct classified operations against extremists. By the early summer 2002, 45,000 Afghan mercenaries were being paid by the CIA (Rashid 2008: 183-184).

Kai Eide, the UN Special Representative to Afghanistan and Head of the United Nations Assistance Mission in Afghanistan (UNAMA) from 2004 to 2010, writes that the President Hamid Karzai's lack of power instruments and financial resources, and the clear message from his powerful ally - the US - that Washington would not engage, meant that he would have to move with great care. According to Karzai, "We understood that the West would not help us free Afghanistan from an environment of warlordism. On the contrary, some were promoted and allowed to keep their militias, to enrich themselves, and to intimidate Afghan villagers. That led to my first disappointment with the West after the fall of the Taliban." (Eide 2014: 12-13) 
Gradually, they became more than warlords and military leaders. As foreign aid began to flow into the country - after a slow start - warlords and corrupt local leaders were the first to enrich themselves. Karzai adds, "They formed contracting companies and received foreign contracts worth hundreds of millions of dollars." (Eide 2014: 12-13)

Frances Vendrell, the UN representative before the Bonn Conference and later Lakhdar Brahimi's (Special Representative of the Secretary-General for Afghanistan 2001-2004) deputy during the Bonn Conference, had also raised the matter with the US officials telling them that they could not fight the Taliban with people who were just as bad as the Taliban. He had added that that would not offer the Afghan people any hope for the future (Eide 2014: 10). However, senior US officials and generals persisted in treating the warlords as head of states, inflating their egos even further. In September 2002 alone, The US Treasury Secretary, John Taylor, visited Ismail Khan (the former Mujahideen commander \& the then Governor) in Heart; Under Secretary of defense and chief financial officer for the US Department of Defense Dov S. Zakheim met with Abdul Rashid Dostum (The Uzbek commander \& the then Deputy Minister of Defense) and Atta Mohammad Noor (Tajik commander of Northern Alliance \& the then Commander of $7^{\text {th }}$ Corps of Northern Afghanistan) in Mazar, while Lt. Gen. Dan K. McNeill, the commander of US led Coalition forces, met with them all. In retrospect, the new US ambassador, Robert Finn, wondered if the U.S. could have done things differently:

None of these warlords were openly defying Karzai, but could the U.S. take the risk, without enough troops in the country to do something about them, that could prompt a civil war? However, we should have moved away from the warlords much earlier and we should have stopped visiting them. We should have supported the government more visibly. I stopped visiting Ismail Khan and Dostum, but Rumsfeld visited them several times. (Rashid 2008: 190-191).

At times, the US has engaged in an ongoing practice of directly supporting favored armed actors outside the state structure at the expense of a broader national government in Afghanistan. This tactic-which initially involved delivering aid in suitcases full of unaccounted money-has been somewhat mitigated by institutionalizing many former warlords and their armed followers into the state security forces and political establishment. But American intelligence and special operations forces are still believed to provide direct funding to local power brokers and militia forces for their support in counterterrorism and counterinsurgency operations. The US has also funded a series of paramilitary and militia efforts-few of which have shown lasting results-parallel to these efforts and to training programs for the Afghan military and police services. The Ministry of Interior and the US led the creation of the Afghan Auxiliary Police force in 
2006, a minimally trained and inadequately paid force intended to provide static checkpoint security in six southern provinces (Cookman and Wadhams 2010: 32).

The armed groups are often informally known as "Campaign Forces", and carry such designations as: Afghan Security Guards, Afghan Guard Forces, Afghan Security Forces, and Critical Infrastructure Police-names that suggest their mission is to protect foreign bases, though many also take part in offensive operations. Created and funded by the US, the US policy from 2004 reaffirmed the utility of these militias, which were supposedly temporary and limited to no more than 2,000 men in total. However, the militias have grown in size far beyond that limitation, and while some may have been integrated into the National Directorate of Security (NDS) command structure, use of the groups continues to this day as a critical part of military operations. (Human Rights Watch 2015: 15) Warlords usually control these militias. Instead of creating new armed groups or militia, Afghan state security forces had to be strengthened and enlarged.

\section{The impact of US support to warlords in Afghanistan}

Warlords have been one of the major sources of chaos and anarchy in the Post-Taliban Afghanistan. Former Afghan President, Hamid Karzai saw warlords one of the biggest threats to his government and hurdle to the reforms his new government was going to introduce. He considered them as rival to his power. But these warlords gained high positions in the post-9/11 Afghan government both in Kabul as well as in the provinces and districts. Many of them became provincial or district governors or security chiefs. They behaved with full impunity despite committing serious human rights violations, including kidnappings, torture, killings, and land grabbing. Karzai once said, "The frustration that we have in this country is that progress has sometimes been stopped by private militias, life has been threatened by private militias, so it should not be tolerated." (Gall and Rohde 2004)

President Karzai once told the former US Secretary of Defense Robert Gates in a private meeting in 2007 in Kabul that the Afghan Northern Alliance were all working against him. In what was, even for Karzai, a particularly conspiratorial frame of mind, he talked about how "inclusiveness" (meaning working with the Northern Alliance) had put the country at risk and that these guys-also described as "Putin Allies" - were now killing parliamentarians and even children. Karzai had told Gates that: "This is not done by the Taliban or al Qaeda but by our own bad people" and his government needed to "consult with the United States on how to handle this." (Gates 2014: 212)

For years, the US continued financial support to these regional commanders and relied upon their forces to engage the Taliban militants. Many ordinary Afghans question the US approach and have been disappointed that the US-led Coalition has not taken a harder stand against the warlords, whom people generally consider to be their abusers. As with many areas of the reconstruction process in Afghanistan, the problem of 
warlordism is one of the biggest impediments to building rule of law and improving governance.

Warlords, whether they hold official positions or not, subvert both formal and informal justice processes through intimidation and interferences in areas from the capital to rural districts, and they largely control whatever law enforcement apparatus exists outside of Kabul, militia men are able to assert control on the streets, despite a semblance of central government police presence (Miller and Perito 2004: 15). Most of them have also been accused of stealing provincial revenues and salaries from the center for their militiamen who are part of national and local police.

A state of anarchy was created in the country even in the presence of US forces as warlords not only challenged and disobeyed the central government of Afghanistan but also competed with one another for power and proclaimed themselves as provincial governors, police chiefs or district governors. In 2002, clashes broke out in the eastern Nangrahar province between two warlords, commander Hazrat Ali and commander Zahir Shah that led to several casualties (UNHCR 2004: 2).

Ismail Khan, an ethnic Tajik and former Mujahideen commander of the Jamiat-eIslami (Islamic Party) became governor of Afghanistan's western Herat province after Taliban were defeated. In 2002, Ismail's militia fought with another former commander in the province, Amanullah Khan, who was an ethnic Pashtun. The clashes led to several casualties on both sides. Then in August 2004, Amanullah Khan attacked the supporters of Ismail Khan, contending that Ismail Khan had not given enough positions to Pashtuns in the largely Pashtun province. Those clashes ended when American-led troops and the Afghan Army were sent in. In September 2004, President Hamid Karzai removed Ismail Khan as governor and appointed him the Minister of Energy and Water where he served till 2014 but he still has considerable influence in Herat. In October 2006, fighting between the followers of two local rival commanders in Herat killed 32 fighters and wounded numerous others (Wafa 2006).

In the North, two warlords of the former Northern Alliance, once ally, turned into opponents over control of northern Balkh province. Fighters of Dostum and Noor clashed in the Northern Afghanistan during 2002 and 2003 that led to several casualties and displacements. The Afghan aid worker said that forces loyal to Dostum forced 180 ethnic Pashtun families out of four villages in the Pir Naqshi area. Some of the women said his militiamen had raped them and looted their homes. The aid worker said Dostum's men had accused the Pashtun families of siding with rival ethnic Tajik forces belonging to the Jamiat-e-Islami (Islamic Party) of Noor during fighting in the area (UNHCR 2004: 4).

General Dostum had supported the Soviets and then switched sides to the mujahideen. He tended to "follow the money" and was therefore happy to align himself with the Americans who sought his support against the Taliban. Although Dostum was a deputy defense minister in the post-Taliban set up, he spent most of his time in the north, 
where his forces collected and kept customs revenues and often battled with Atta Noor's forces. (Zakheim 2011:180) Human rights groups have accused Dostum of widespread looting, mass executions, rapes and other severe crimes in the north of Afghanistan.

Atta Mohammad Noor - a former anti-Soviet Mujahideen commander, on the other hand, was Commander of $7^{\text {th }}$ corps of northern Afghanistan based in the Balkh's provincial capital, Mazar-e Sharif. He had developed a network of sub-commanders and militiamen in the north of the country. Being part of NA, he also joined US forces to fight against the Taliban in Balkh province. Noor forged himself as Karzai's ally in the north of Afghanistan and Karzai later appointed him as the governor of Balkh in 2004. However, he later turned against Karzai in 2009 presidential elections but Karzai even after winning the election kept him as the governor of Balkh province. Human Rights Watch writes in its 2015 report that several of Noor's commanders within the security services have operated criminal gangs that have been involved in kidnappings and killings, among other abuses (Human Rights Watch 2015: 41). Within just a few years, Noor became one of the richest and most powerful persons in the country.

Noor served as the governor of Balkh, a strategic province that borders Uzbekistan, for 14 years, before President Ashraf Ghani fired him in December 2017. However, Noor refused to leave his post and powerbase and left the office only in March 2018 after defying Ghani's order for months. While addressing a huge gathering in Mazar-e-Sharif on 21 March 2018 after a deal with President Ghani, Noor said that he welcomed and supported the agreement between the Presidential Palace and his party, Jamiat-e Islami. He added that the agreement said that one of his three nominees would be appointed as the next governor of Balk province after his departure from the post. He added, "I have said many times that no one can remove me with a decree." (Arian and Siddique 2018) Even after his departure, Noor's imposing image is everywhere in Balkh, and many people say he is still in charge. His appointed replacement, Governor Mohammad Ishaq Rahgozar, referred to Noor as "Excellency" and the local government TV channel gives Noor's activities and pronouncements much greater prominence (Hassan 2018).

Then on 14 March 2019, gunfire broken out in Mazar-e-Sharif between armed militia loyal to Noor and Interior Ministry forces sent to support a new police chief, who was appointed by President Ashraf Ghani. The fighting erupted as the Interior Ministry's forces were escorting the newly appointed police chief, Abdul Raqib Mobarez, to the provincial police headquarters, who finally got to the headquarter and took the charge. Thirteen people were injured during the clashes. Noor wanted to appoint the police chief of his choice in the northern Balkh province (RFERL 2019).

The US ambassador to Afghanistan, John R. Bass, issued a twitter statement on the same day (March 14) calling on both Noor and President Ghani to instruct the forces and police under their command "to stand down, and for political leaders on both sides of the dispute to put the Afghan people first." Bass said, "Afghan security forces are tasked with protecting the Afghan people, not fighting each other over political disputes." He also 
called it "green on green" violence, which he added "is unacceptable" and that "the only ones who benefit from this violence are the Taliban." (Bass 2019) Many Afghan citizens replied Ambassador Bass on twitter and other social media platforms and questioned his approach by saying that the U.S. must stand with the State and shouldn't be supporting warlords, criminals, human rights abusers and drug traffickers. After spending less than a month as provincial police chief of Balkh, Mobarez was replaced by Ajmal Fayez on 13 April. Noor celebrated the appointment of new police chief and thanked the defense and interior ministries to fulfill the commitment they had made with him (Noor 2019).

According to Abdul Karim Khurram, former minister for information and culture and the chief of staff of Afghanistan's former President Hamid Karzai, the US tried to protect the illegitimate power of local power brokers, warlords and strong men because Washington considered them beneficial for the fulfilment of their goals in Afghanistan. "The former President Hamid Karzai frequently told Americans that when they needed a warlord, they didn't talk about warlordism and human rights and kept them as allies. The US raised these issues for political reasons and at times when they wanted to pressurize someone." (Khurram 2019)

Khurram cites an incident: "General Dostum was supported by the US after he had attacked his rival Akbar Bai in 2005. When the Attorney General of Afghanistan ordered Dostum's arrest, the US directly interfered and sided with Dostum through inserting pressure on the Afghan government not to act against Dostum." (Khurram 2019)

The US supported warlords not only militarily but also politically and economically by granting them cash as well as huge contracts for reconstruction projects in areas they controlled. They still have considerable influence in their areas and have a big say in the political affairs of the country. "Years of warfare and the collapse of a functioning central government had led to the formation of parallel power structures at the local level, often headed by local commanders." (Suhrke 2007: 1301) Ashraf Ghani's choice of Dostum to become his First Vice-Presidential candidate in the 2014 presidential election was a confirmation of their continued power and influence. "The person who was called the ultimate reformer (Ashraf Ghani) had chosen the ultimate warlord (Dostum) as his primary running mate." (Eide 2014: 11)

Abdul Rab Rasul Sayyaf is another influential figure in the country. He was the leader of one of the mujahideen factions fighting against the Soviet occupying forces in Afghanistan during the 1980s and was generously financed and apparently favored by Saudi Arabia. Sayyaf has also been accused by Human Rights groups of serious human rights abuses and land grabbing in and around Kabul. He was elected as member of the parliament in 2004 and 2009 from Kabul while one of his sons was elected to the parliament in the 2018 general elections. President Ashraf Ghani invited Sayyaf to preside over the Peace Consultative Loya Jirga (Grand Council) in Kabul in April 2019. This grand 
assembly of over 3,200 delegates from around the country discussed the ways to negotiate a peace deal with Taliban.

In southern Afghanistan, many former mujahideen commanders became government officials in the post-Taliban Afghanistan and made millions of dollars in just a few years through US contracts as well as revenue generated locally. Gul Agha Sherzai, a former mujahideen commander during the Soviet occupation, became governor of Kandahar province in 2001. However, he resisted President Karzai's order to be removed from the position of the governor of Kandahar in 2004. Agha Lalai Dastagiri, the current Deputy Governor of Kandahar province and an influential politician in the province witnessed when Gul Agha Sherzai was replaced as the governor of the province and was appointed as a minister in the central government by President Karzai. According to Dastagiri:

Sherzai became really upset and even tried to rebel against President Karzai but the people of the province convinced him not to do so. Finally, after long negotiations with the central government, Engineer Yousaf Pashtun was appointed as the governor of Kandahar on his recommendation and later, he accepted the Ministry of Urban Development and Housing. (Dastagiri 2018)

Dastagiri elaborates the presence of warlords in various parts of the country. "There were warlords everywhere who challenged the writ of the central government including Sher Muhammad Akhundzada in Helmand province, Hamidullah Khan in Zabul province and Jan Muhammad Khan in Urozgan province who were not accountable to the central government." (Dastagiri 2018)

General Abdul Raziq, the police chief of Kandahar province, who was shot dead in an insider attack on 18 October 2018 in Kandahar's governor office, also challenged President Ghani that no power could remove him from his position. Speaking to journalists on 3 January 2018, General Raziq said that he was serving as provincial police chief because the locals wanted him to be there. "I have not been appointed by this government, and it cannot fire me. I am serving because the people of Kandahar want me to serve, and I will only leave this post if they tell me to do so." (RFERL 2018a) "Raziq enjoyed the support of the US military and US officials." (Human Rights Watch 2015: 73)

The warlords managed to find way to the parliament and created problems for the young and educated Afghans to enter politics and parliament. A striking example of the deleterious effects of the accommodationist strategy of the state-building process concerns the parliamentary elections in September 2005. Afghanistan's electoral law (Article 15, No. 3) "prohibits anyone who commands or belongs to an unofficial military force or armed group from becoming a candidate". A vetting process was established to review candidates, and a list of 1,024 individuals with potential links to armed groups was 
compiled by the Demobilization and Reintegration Commission, which maintained a countrywide database of illegal armed groups (Hodes and Sidra 2007: 13-14). The list of these individuals was referred to the Independent Electoral Complaints Commission (IECC) but in the end, only 54 candidates were barred; 34 because of links to armed groups, 12 for refusal to resign from public office, five for lack of adequate signatures on supporting petitions and three for intimidation and fraud. However, no one was excluded under the provision banning "funds originating from illegal activities" (International Crisis Group 2006: 4) Several warlords became parliamentarians after the 2010 and 2018 parliamentary elections.

According to Zabihullah Sadaat, the spokesperson of Independent Election Commission of Afghanistan (IEC), the representation of people and to become a parliamentarian was considered a kind of power symbol and prestige rather than a responsibility. Sadaat added:

Several warlords found their way to the parliament who had black money and were linked to the drug mafia or narcotics. The people who deserved to be parliamentarians couldn't have the chance to get to the parliament. This had a negative impact on the electoral process and also became a hurdle in the implementation of the rule of law. Most of the elected MPs were not competent enough to introduce reforms or enact a bill or law in the parliament. As a result, many people were unsatisfied with the electoral system and democracy itself. (Sadaat 2019)

Zabihullah Zmaray, the Vice Chairman of Provincial Council of Afghanistan's eastern Nangrahar province says that US supported warlords both in arms and money to use them against Taliban as foot soldiers and also continued to support them after the fall of Taliban. "Warlords were funded by American CIA (Central Investigation Agency) and PRTs (Provincial Reconstruction Teams) and were given them contracts. Now the warlords have huge amount of money that they use it sometimes in elections and sometimes for other personal interests." (Zmaray 2018)

The international community especially the US, also largely ignored warlords' involvement in the opium trade in exchange for their help in fighting al-Qaida and the Taliban. The US' dependence on warlords to further its political and military agenda has been detrimental to the disarmament program, creation of a national army and police force, conduct successful anti-narcotics operations and, above all, building institutions, providing good governance and extending Kabul's authority in the provinces and districts (Chandra 2006: 81).

Besides narcotics, warlords are also involved in the illegal extraction and smuggling of minerals in Afghanistan. The European Union says only eight percent of mining is legal in Afghanistan. "The broad range of stakeholders going from insurgents 
over warlords, local strongmen to government officials, security forces - a very large group of people's interests are involved. This is also a signal of the danger that if this is not countered now, it can become a serious threat." (Mellbin 2016)

The Afghan warlords used the money and arms they received (from the US) to invest in "drug production and engage in land grabs, predation, political intimidation, and ethnic cleansing - a major source of insecurity for Afghans." (Rubin 2006b: 5-6)

Warlords continued to exploit their power, influence and control over resources. As Atta Muhammad Ahmadi, a local elder in southern Kandahar province says, "Warlords oppressed people and grabbed their lands and properties, and as a result, there is no rule of law and check and balance. There is chaos. No one is afraid of the government and there is no one in the government to whom you could present your case or complaint." (Ahmadi 2018)

Warlords entered the security sector and instead of enforcing the law, they violated it. As one observer says, "several semi-literate or illiterate and untrained persons were given the ranks of generals in the army and police." (Mujahid 2018) In addition to Afghan National Army (ANA) and Afghan National Police (ANP), the Afghan Local Police (ALP) force was approved by the Afghan government in July 2010 and was established by a presidential decree on 16 August 2010. According to the US military and the Afghan government, the ALP is being rolled out across the country to defend rural communities in areas where there is limited Afghan national army and police presence and while the national forces strengthen their capabilities. "The US military provided the funds and was the primary driver behind the creation of the ALP." (Human Rights Watch 2015: 4) But several warlords lead the ALP in many parts of the country who have been accused of illegal detentions, torture, killings, looting and even rape (Masoom 2018).

The Afghan parliamentarian from the country's southern Uruzgan province Ubaidullah Barkazai, who was assassinated by unknown gunmen in early 2019, told me, "The US strengthened and financed mostly those warlords and depended on those people who were murderers, mafia, smugglers, land grabbers and/or rights violators." (Barakzai 2018)

Barakzai added, "The U.S. used some warlords and militiamen to raid houses and kill or capture people in the name of targeting the Taliban". (Barakzai 2018) He named Hakeem Shujayee - an ethnic Hazara commander - whom he said was working with the US Special Forces." (Barakzai 2018) Human Rights Watch had also accused Shujayee of human rights abuses and as someone who had also ties with the US forces (Human Rights Watch 2015: 23).

According to a former governor of Uruzgan province, the US Special Forces protected Shujayee despite all human rights abuses he had committed.

The US Special Forces had a base in Khas Rozgan/Tarinkot [the capital city of Uruzgan province] and they were providing weapons to Shujayee. We got several complaints and 
later wrote letters to US officials that Shujayee and another local warlord were taking money from locals, torching their houses, handing the innocent people to US forces portraying them as Taliban, etc. After consultation with International Security Assistance Force (ISAF) commander, I went to Khas Uruzgan in helicopter along with ISAF commander and US Special Forces soldiers and called both Shujayee and another local police commander. After talking to them, we arrested both of them. By the time we were ready to fly back along with these two 'bad guys', Shujayee disappeared. Actually, the Special Forces had protected him. (Ex-Governor n.d)

He added that this was the reason that "the local hatred increased against the US, both in Uruzgan province and other parts of the country." (Ex-Governor n.d.)

Warlords in Afghanistan use their weapons and militias for their personal interests. Reports say that most of the Afghan Local Police are linked to warlords with many of them operating criminal gangs involved in kidnappings and killings, among other abuses (Human Rights Watch 2015: 41). There were an estimated 2,000 illegal or informal armed groups with more than 100,000 members continue to operate in various parts of Afghanistan. Abdul Khaliq Balakarzai, a local elder, who served as both military officer and mujahideen commander, says the "brutality" of warlords coerced several people to turn against the government.

A major reason of most of the misdeeds and chaos in the country is the activities of illegal militias linked to warlords. This is also a major reason that several people joined the Taliban and took arms in retaliation of injustices and brutality they suffered at the hands of these warlords and militias. (Balakarzai 2018)

The illegal armed militias of Nizamuddin Qaisari, an ethnic Uzbek and Abdul Ghani Alipur, an ethnic Hazara are not only accused of killing civilians but also have been engaged in fighting against Afghan National Security Forces (ANSF). Alipur, who is also known as "Commander Sword", has private militia and was arrested by Afghan government on 24 November 2018. Alipur's release on bail on November 26 came after two days of demonstrations in which hundreds of Hazara protesters clashed with police in Kabul. The Interior Ministry said 48 police officers were wounded and eight police checkpoints set on fire during two days of demonstrations (RFERL 2018b). Later, while on 30 January 2021, Afghan security forces went to arrest Alipur in the country's central Wardak province, his militiamen clashed with security forces where nine people were killed and seven others wounded including Afghan security forces (BBC Pashto 2021). In another incident on 18 March 2021, Alipur's militants shot down an Afghan air force helicopter in Behsud district of Afghanistan's central Maidan Wardak province where nine people including four Afghan pilots were killed (Gibbons-Neff and Rahim 2021). Many locals in 
Wardak province say Alipur is involved in human rights abuses and torturing and killing of people by the name of Taliban (Wais et al. 2018).

On the other hand, Nizamuddin Qaisari, who is backed by Abdul Rashid Dostum, was the former police chief of Qaisar district in Afghanistan's northern Faryab province. Once arrested in 2018 for few months and later released, Qaisari was involved in extortion of money from people, defying the central government and several other human rights violations (Qadir 2019). A year later in December 2019, Qaisari managed to escape after security forces raided his compound in northern Balkh province. The clash between security forces and Qaisari's gunmen left at least 12 people dead from Qaisari's militia. Security forces were also reported to be killed and wounded in the clash (Pajhwok 2019). Both Qaisari and Alipur still possess illegal armed militias which pose a serious threat to law and order in the country.

The US has spent hundreds of billions of dollars on its military operations in Afghanistan. A high-ranking Afghan government official told me on the condition of anonymity due to security and administrative sensitivities that there were many off budget projects controlled by the US military where the money was given to the local commanders and warlords. "The US converted the warlords in various parts of Afghanistan into millionaires and in some cases even billionaires. Warlords had been the main beneficiaries of the US money spent in Afghanistan." (Jan 2018)

Fazl-ul-Khaliq Lalmawal, a professor of Kandahar University in Afghanistan's southern Kandahar province stated that the US supported warlords in all parts of the country because it didn't want these warlords to be fallen into the hands of intelligence agencies of countries of the region (Lalmawal 2018). However, Faiz Muhammad Zaland, a professor of Kabul University believes that if this was the intention, it hasn't worked. According to him, these warlords have become much more powerful and influential that, on top of their links with the US, they have also made contacts with other countries, especially in the region. He states that "warlords were not the true partners of the US. They were just laborers and who ever gives them more money, they will go for them." (Zaland 2018)

A number of educated and politically aware Afghans are of the opinion that warlords are treated as state building actors and used in regime security in Afghanistan. Faiz Muhammad Zaland, says that "even now, our destiny is being decided by the armed groups and warlords who fought against the Soviet troops in the 1980s." (Zaland 2018) He accuses the US for not investing in the true representatives of the Afghan people and helping them to come forward, instead, they were suppressed by the warlords (Zaland 2018). On the other hand, an Afghan parliamentarian told me "the US trusted the warlords who were responsible for the dire situation in Afghanistan." (Katawazai 2018)

According to a former spokesperson of Afghan President Ashraf Ghani, the US didn't have a Plan-B after the fall of Taliban. "The US planted warlords in the new Afghan government that stalled the state-building process. Both in Karzai and Ghani 
governments, the expectation from the US was to stand beside the Afghan government against warlords and this is something which is not yet fully fulfilled." (Azad 2018)

However, Abdul Karim Kurram believes that it has been a deliberate US policy to support warlords and keep the Afghan government under constant pressure. He says that the US wanted a weak and divided government in Afghanistan and favored to deal with several individuals within the government rather than the government as single entity (Khurram 2019).

Warlords were on one hand, directly funded by the US, especially the CIA, they got several lucrative contracts from US military and civilian agencies on the other hand. The US-led invasion of Afghanistan in 2001 contributed to a boom in the private security business. In 2010, a presidential decree by Hamid Karzai banned all private security companies in Afghanistan after a series of scandals. "In 2012, for example, there were more than 100,000 contractors - armed and unarmed - employed by the US Department of Defense. That included more than 20,000 private security contractors. The number of private security contractors went down later but has slightly increased in recent years." (BBC 2018) Again, warlords were in the front line to establish private security companies. They were direct beneficiaries of this scheme who received millions of dollars through contracts from the US in various parts of the country. These companies were tasked to carry and protect the logistics of US and other international forces to various military bases in the Afghanistan.

In a 79-page report produced by the United States Subcommittee on National Security and Foreign Affairs entitled, Warlord, Inc.: Extortion and Corruption Along the U.S. Supply Chain in Afghanistan, the subcommittee Chairman states that the arrangements made by the US Department of Defense in outsourcing the security for transporting their supplies has fueled a vast protection racket run by a shadowy network of warlords, strongmen, commanders, corrupt Afghan officials, and perhaps others. According to the report the principal contract supporting the US supply chain in Afghanistan is called Host Nation Trucking (HNT), a US $\$ 2.16$ billion contract split among eight Afghan, American, and Middle Eastern companies. Although there are other supply chain contracts, the HNT contract provides trucking for over 70 percent of the total goods and materiel distributed to US troops in the field, roughly 6,000 to 8,000 truck missions per month. The trucks carry food, supplies, fuel, ammunition, and even Mine Resistant Ambush Protected vehicles (MRAPs) (U.S. House of Representatives 2010: 1). The report adds that:

The principal private security subcontractors on the HNT contract are warlords, strongmen, commanders, and militia leaders who compete with the Afghan central government for power and authority. Providing protection services for the US supply chain empowers these warlords with money, legitimacy, and a raison d'etre for their private armies. Although many of these warlords nominally operate under private security companies licensed by the Afghan Ministry of Interior, they thrive in a vacuum 
of government authority and their interests are in fundamental conflict with US aims to build a strong Afghan government. (U.S. House of Representatives 2010: 2)

The report states that within the HNT contractor community, many believe that the highway warlords who provide security in turn make protection payments to insurgents to coordinate safe passage. This belief is evidenced in numerous documents, incident reports, and e-mails that refer to attempts at Taliban extortion along the road (U.S. House of Representatives 2010: 3). Officials at the US and Development Alternatives, Inc. (DAI) expressed concerns that insurgents may have extorted protection payments amounting to as much $\$ 5.2$ million in 2009 from Afghan representatives carrying out projects in remote areas under the USAID-funded Local Governance and Community Development program. The program is designed to show residents in contested regions of Afghanistan that the US-backed government is capable of providing basic services (Lynch 2010).

The US strategy not only strengthened a number of former mujahideen commanders and warlords in Afghanistan, it also provided opportunity for others to become warlords, create militia groups, and get access to resources in the name of fighting against the Taliban and/or al-Qaeda. According to a former member of Afghanistan's lower house of parliament from southern Kandahar province, the contractors who are paid by the US send millions of dollars every year to the Taliban's leadership and their local groups for safe exit and smooth transportation of logistics (Ayubi 2019). Abdul Hakim Noorzai, the former Deputy National Security Advisor of Afghanistan is of the view that the US provided both money and positions to the warlords which was not a successful strategy of the US state building in Afghanistan. "Every aid that was meant for the Afghan government, was actually for warlords. These people looted the system as well as the American aid." (Noorzai 2018)

The former Afghan Minister of Interior Ali Ahmad Jalali says that "some of the most prominent warlords remained among the most privileged partners of the US with regards to both economic projects and political cooperation." (Eide 2014: 1) Finally, whether called "businessmen," "commanders," "strongmen," "militia leaders," or "warlords," any single individual who commands hundreds or thousands of armed men in regular combat and operates largely outside the direct control of the central government is a competitor to the legitimacy of the state (U.S. House of Representatives 2010: 20).

\section{Conclusion}

Warlords in Afghanistan are the product of the Afghan Jihad or armed struggle against the Soviet occupation of the country from 1979 to 1989. They had private militias and control over a specific territory where they collected revenues. However, warlordism has remained as one of the most persistent challenges of post-Taliban Afghanistan. Following the fall of the Taliban regime in Afghanistan in 2001, the US spent a lot of blood and 
treasure in the country helping to build state institutions and critical infrastructure. However, along the ways, the US policy makers also made a number of mistakes, which undermined its own stated mission and goals. At many occasions, it invested in the wrong people and the wrong projects. It is ironic that many prominent warlords have been among the most privileged US partners.

Early on, the US allied with Afghan warlords, many of whom had committed war crimes and grave human rights abuses against fellow Afghans. The US provided huge sums of money and weapons to the former Mujahideen-turned warlords after 9/11 as part of its War on Terror aimed at defeating and dismantling the al-Qaeda network and its allies. Although the US financial and military support to the Afghan warlords brought short term benefits as it may have helped to accelerate the fall of the Taliban regime and disrupt the al-Qaeda network in the country, the overall impact of this policy proved detrimental to the larger objectives and was associated with several negative consequences for both stability and state building as well as the nascent democracy in the country.

Warlords were on one hand, directly funded by the US, especially the CIA; on the other hand, they got several lucrative contracts from US military and civilian agencies. In addition, they captured and corrupted state institutions, looted and stole money from the treasury and public goods, and intimated population in a variety of ways thus undermining the battle of winning hearts and minds of the population.

Warlords, who had been mostly expelled and/or defeated by the Taliban regime returned under the shadows of the US' B-52 bombers, recaptured parts of the state and re-established their fiefdoms with the US support and resources. US agencies, particularly those in the military and intelligence communities, relied on these warlords for different reasons, including historical relationships; intelligence; information; political needs in Kabul or provinces; and as security force multipliers or force protectors.

Warlords accumulated more power over the years and have become a major hurdle to improve governance and enact necessary reforms in the country. They continue their exploitations, maintain private militias, and have links to criminal networks. Warlords have now infiltrated almost every institution, which has both directly and indirectly affected the lives of nearly all of citizens in Afghanistan.

Warlords have now become one of the biggest impediments for implementing the rule of law and improving good governance. In addition, the US strategy not only strengthened a number of former mujahideen commanders and warlords in Afghanistan, it also provided opportunity for them to become rich and powerful, create and maintain militia groups, and get access to resources in the name of fighting against the Taliban and/or al-Qaeda. Apart from land grabbing and illegal extraction and smuggling of minerals, most of warlords have also been involved in severe human rights abuses as well as drug trafficking, arms smuggling and extortion in areas they control or influence. This has made the situation in Afghanistan more complicated and the resolution of the ongoing 
conflict much harder. There are more windows open for further research on the US support to Afghan warlords and its impact on the rule of law, good governance, democratization and government delivery to the Afghan people.

\section{References}

Ahmadi, A.M. 2018. Personal interview with Atta Muhammad Ahmadi, an elder from Afghanistan's Southern Kandahar province. 27 July 2018.

Arian, A. and Siddique, A. 2018. "Defiant Governor Reaches Agreement with Kabul." Radio Free Europe/Radio Liberty. 21 March 2018. [online]. [cit. 14. 5. 2019]. Available at: https://gandhara.rferl.org/a/Afghanistan-atta-mohammad-noor-ghani/29113319.html

Ayubi, A.R. 2019. Personal interview with Abdul Rahim Ayubi, member of the Lower House of Afghanistan's Parliament - Wolasi Jirga (2010 to 2019). 11 January 2019.

Azad, N. 2018. Personal interview with former deputy spokesperson of Afghan President Ashraf Ghani \& former advisor to NATO. 15 August 2018.

Azami, A.S. 2020. “The Post-9/11 US-Led State-Building in Afghanistan.” Central European Journal of Politics $6(1): 1-25$.

Balakarzai, A.K. 2018. Personal interview with Major retired Abdul Khaliq Balakarzai, a former Afghan military officer, former Mujahideen commander and a local elder. 28 July 2018.

Barakzai, U. 2018. Personal interview with Ubaidullah Barakzai, member of Afghanistan's lower house of the parliament - Wolasi Jirga (2010 to 2019). 11 August 2018.

Bass, J.R. 2019. Twitter. 14 March 2019. [online]. [cit. 14. 5. 2019]. Available at: https://twitter.com/USAmbKabul/status/1106182435224674304?s=20

BBC. 2018. "What are Private Security Companies Doing in Afghanistan?" British Broadcasting Corporation.

2 December 2018. [online]. [cit. 17. 4. 2019]. Available at: https://www.bbc.com/news/world46400647

BBC. 2016. “Who Are the Taliban?” British Broadcasting Corporation. 26 May 2016. [online]. [cit. 11. 3. 2019]. Available at: https://www.bbc.com/news/world-south-asia-11451718

BBC Pashto. 2021. “Govt. Delegation in Wardak to Investigate Clash Between Alipur's Militia and Security Forces." British Broadcasting Corporation Afghan (Pashto) Service. 31 January 2021. [online]. [cit. 31. 1. 2021]. Available at: https://www.bbc.com/pashto/afghanistan-55877018

Bolger, D.P. 2014. Why We Lost: A General's Inside Account of the Iraq and Afghanistan Wars. New York: Houghton Mifflin Harcourt.

Burchill, S. et al. 2009. Theories of International Relations. New York: Palgrave Macmillan.

Chandra, V. 2006. "Warlords, Drugs and the War on Terror in Afghanistan: The Paradoxes." Strategic Analysis 30 (1): 64-92.

Cookman, C. and Wadhams, C. 2010. Governance in Afghanistan: Looking Ahead to What We Leave Behind. Washington, D.C.: Center for American Progress. 
Dastagiri, A.L. 2018. Personal interview with Agha Lalai Dastagiri, the Deputy Governor of Afghanistan's Southern Kandahar province \& Advisor to the Afghan President Ashraf Ghani for Social Affairs. 26 July 2018.

Eide, K. 2014. Afghanistan and the US: Between Partnership and Occupation. Oslo: Peace Research Institute.

Ex-Governor. (n.d.). Personal interview with Ex-Governor of Afghanistan's Southern Uruzgan province. (Date of the interview \& name of Ex-Governor have been kept anonymous as the respondent didn't want to be identified for security reasons).

Franks, T. R. 2004. American Soldier. New York: Harper Collins.

Gall, C. and Rohde, D. 2004. "Afghan President Describes Militias as the Top Threat." New York Times. 12 July 2004. [online]. [cit. 13. 5. 2019]. Available at: https://www.nytimes.com/2004/07/12/world/afghanpresident-describes-militias-as-the-top-threat.html

Gates, R.M. 2014. Duty: Memoirs of a Secretary at War. New York: Alfred A. Knopf.

Gibbons-Neff, T. and Rahim, N. 2021. "At Least Nine Dead in Afghan Helicopter Crash, after Clashes with Local Militia." New York Times. 18 March 2021. [online]. [cit. 22. 3. 2021]. Available at: https://www.nytimes.com/2021/03/18/world/asia/afghanistan-helicopter-crash-militias.html

Ginty, R.M. 2010. "Warlords and the Liberal Peace: State-building in Afghanistan." Conflict, Security \& Development 10 (4): 577-598. https://doi.org/10.1080/14678802.2010.500548

Giustozzi, A. 2010. "Don't Call That Warlord a Warlord." Foreign Policy Magazine. 25 February 2010. [online]. [cit. 10. 3. 2019]. Available at: https://foreignpolicy.com/2010/02/25/dont-call-that-warlorda-warlord-2/

Giustozzi, A. 2005. The Debate on Warlordism: The Importance of Military Legitimacy. Discussion Paper No. 13 Crisis States Research Center. London: London School of Economics.

Gómez-Castro, D. 2017. "A Spartan Warlord: Lysander and the Creation of a New Greek Empire." In: T.Ñ. del Hoyo and F.L. Sánchez (eds.). War, Warlords, and Interstate Relations in the Ancient Mediterranean. Leiden: Brill, 54-63. https://doi.org/10.1163/9789004354050_005

González, J.P. 2017. “Commanders and Warlords in Fourth Century BC Central Greece.” In: T.Ñ. del Hoyo and F.L. Sánchez (eds.). War, Warlords, and Interstate Relations in the Ancient Mediterranean. Leiden: Brill, 89-112. https://doi.org/10.1163/9789004354050_007

Hassan, S. 2018. "Ousted but not out: Afghan Strongman Still Calls the Shots, Residents Say." Washington Post. 13 May 2018. [online]. [cit. 14. 5. 2018]. Available at: https://www.washingtonpost.com/world/asia_pacific/ousted-but-not-out-afghan-strongman-stillcalls-the-shots-residents-say/2018/05/11/e384e598-52f0-11e8-a6d4ca1d035642ce_story.html?utm_term=.eb8b82f35c67

Havercroft, J. and Prichard, A. 2017 "Anarchy and International Relations theory: A reconsideration." Journal of International Political Theory 13 (3): 252-265. https://doi.org/10.1177/1755088217719911

Hobbes, T. 1894. Leviathan: Or the Matter, Form and Power of a Commonwealth, Ecclesiasticall and Civil (4th Edition). London: George Routledge and Sons Limited.

Hodes, C. and Sedra, M. 2007. The Search for Security in Post-Taliban Afghanistan. London: The International Institute for Strategic Studies. https://doi.org/10.4324/9780203759301 
Holsti, K.J. 1996. The State, War and the State of War. Cambridge: Cambridge University Press. https://doi.org/10.1017/CB09780511628306

HRW. 2015. Today We Shall All Die: Afghanistan's Strongmen and the Legacy of Impunity. New York: Human Rights Watch. https://doi.org/10.1163/2210-7975_HRD-2156-2015060

ICG. 2006. Afghanistan's New Legislature: Making Democracy Work. Asia Report no. 116. Brussels: International Crisis Group.

Jan, A. 2018. Personal interview with a high rank Afghan official in Kabul whose pseudo name has been used for security purposes. 13 August 2018.

Katawazai, N.K. 2018. Personal interview with Nadir Khan Katawazai, Member of the Lower House of Afghan Parliament - Wolasi Jirga. 14 August 2018

Kessler, R. 2003. The CIA at War: Inside the Secret Campaign Against Terror. New York: St. Martin's Press.

Khalilzad, Z. 2016. The Envoy: From Kabul to the White House, My Journey Through a Turbulent World. New York: St. Marin's Press.

Khurram, A.K. 2019. Personal interview with Abdul Karim Khurram: The Chief of Staff to Afghanistan's former President Hamid Karzai \& Former Minister for Information and Culture Afghanistan. 22 February 2019.

Lalmawal, F.K. 2018. Personal interview with Fazl-ul-Khaliq Lalmawal, Dean Faculty of Law \& Political Science, Kandahar University. 27 July 2018.

Lynch, C. 2010. “US Tax Money Goes to Taliban.” Foreign Policy Magazine. 30 September 2010. [online]. [cit. 19. 4. 2019]. Available at: https://foreignpolicy.com/2010/09/30/u-s-tax-money-goes-to-taliban/

Marten, K. 2012. Warlords: Strong Arm-Brokers in Weak States. Ithaca/London: Cornell University Press. https://doi.org/10.7591/9780801464119

Masoom, M. 2018. Personal interview with a local in Afghanistan's Southern Kandahar province. 28 July 2018.

Mellbin, F. S. 2016. Personal interview with Franz-Michael Skjold Mellbin, the Ambassador of EU to Afghanistan. 2 May 2016.

Miller, L. and Perito, R. 2004. Establishing the Rule of Law in Afghanistan. Washington, D.C.: United States Institute of Peace.

Mujahid, A.H. 2018. Personal interview with Abdul Hakim Mujahid, former Deputy Head of Afghanistan High Peace Council \& former Permanent Ambassador of Afghanistan During Taliban Regime to the United Nations. 10 August 2018.

Mukhopadhyay, D. 2014. Warlords, Strongman Governors, and the State in Afghanistan. New York: Cambridge University Press. https://doi.org/10.1017/CB09781139161817

Noor, A.M. 2019. Facebook. 13 April 2019. [online]. [cit. 14. 5. 2019]. Available at: https://www.facebook.com/gen.noor/posts/1583787805087865

Noorzai, A.H. 2018. Personal interview with Abdul Hakim Noorzai, former Deputy National Security Advisor of Afghanistan. 15 August 2018.

Pajhwok. 2019. “A Dozen Gunmen Killed in Raid on Qaisari’s House.” Pajhwok Afghan News. 16 December 2019. [online]. [cit. 31. 1. 2021]. Available at: https://pajhwok.com/2019/12/16/dozen-gunmen-killedraid-qaisari-house/ 
Patton, M.Q. 2002. Qualitative Research and Evaluation Methods. Thousand Oaks: Sage.

Peceny, M. and Bosin, Y. 2011. "Winning with warlords in Afghanistan." Small Wars \& Insurgencies 22 (4): 603-618. https://doi.org/10.1080/09592318.2011.599166

Qadir, A. 2019. Personal interview with an Afghan security official who was not authorized to talk, therefore, his pseudo name has been used. 11 April 2019.

Rashid, A. 2008. Descent into Chaos: The United States and the Failure of Nation Building in Pakistan, Afghanistan, and Central Asia. New York: Penguin Group.

RFERL. 2018a. "Afghan Provincial Police Chief Says Government Cannot Fire Him." Radio Free Europe/Radio Liberty. 3 January 2018. [online]. [cit. 15. 5. 2019]. Available at: https://gandhara.rferl.org/a/afghanistan-kandahar-general-abdul-raziq/28953359.html

RFERL. 2018b. "Afghan Authorities Release Militia Leader after Violent Demonstrations." Radio Free Europe/Radio Liberty. 26 November 2018. [online]. [cit. 31. 1. 2021]. Available at: https://www.rferl.org/a/supporters-of-hazara-militia-leader-protest-in-kabul-forsecondday/29621253.html

RFERL. 2019. "Rival Police Clash in North Afghan City in Spat Between President, Ex-Governor." Radio Free Europe/Radio Liberty. 14 March 2019. [online]. [cit. 14. 5. 2019]. Available at: https://www.rferl.org/a/north-afghan-city-shut-down-amid-spat-between-powerful-ex-governorpresident/29820887.html

Rich, P.B. 1999. “The Emergence and Significance of Warlordism in International Politics.” In: P.B. Rich (ed.). Warlords in International Relations. London: Macmillan, 1-16. https://doi.org/10.1007/978-1-34927688-2_1

Rubin, B.R. 2006a. "Peace Building and State-Building in Afghanistan: Constructing Sovereignty for Whose Security?" Third World Quarterly 27 (1): 175-185. https://doi.org/10.1080/01436590500370038

Rubin, B.R. 2006b. Afghanistan's Uncertain Transition from Turmoil to Normalcy. Council Special Report No. 12. New York: Council on Foreign Relation Press.

Rumsfeld, D. 2011. Known and Unknown: A Memoir. New York: Penguin Press. http://dx.doi.org/10.1163/2468-1733_shafr_SIM260030022

Sadaat, Z. 2019. Personal Interview with Zabihullah Sadaat, the Spokesperson of Independent Election Commission of Afghanistan. 11 January 2019.

Schetter, C., Glassner, R., and Karokhail, M. 2007. "Beyond Warlordism: The Local Security Architecture in Afghanistan." Internationale Politik und Gessellschaft, Referat Internationale Politikanalyse 2 (2): 136152.

SIGAR. 2016. Corruption in Conflict: Lessons from the U.S. Experience in Afghanistan. Arlington: Special Inspector General for Afghanistan Reconstruction.

Suhrke, A. 2007. "Reconstruction as Modernization: The Post Conflict Project in Afghanistan." Third World Quarterly 28 (7): 1291-1308. https://doi.org/10.1080/01436590701547053

Tuplin, C. 2017. “Mercenaries and Warlords in the Achaemenid Empire.” In: T.Ñ. del Hoyo and F.L. Sánchez (eds.). War, Warlords, and Interstate Relations in the Ancient Mediterranean. Leiden: Brill, 17-35 https://doi.org/10.1163/9789004354050_003 
UNHCR. 2004. Chronology of Events in Afghanistan. Geneva: United Nations High Commissioner for Refugees.

U.S. House of Representatives. 2010. "Warlord, Inc. Extortion and Corruption Along the U.S. Supply Chain in Afghanistan." Report of Subcommittee on National Security and Foreign Affairs, United States House of Representatives, Washington D.C.

Wafa, A.W. 2006. “32 Killed in Factional Fighting in Western Afghanistan.” New York Times. 23 October 2006. [online]. [cit. 13.2019 ]. $5 . \quad$ Available https://www.nytimes.com/2006/10/23/world/asia/23afghan.html

Wais, M. et al. 2018. Discussion with a group of people from Afghanistan's central Wardak province. 15 August 2018.

Waltz, K. N. 1979. Theory of International Politics. Boston: Addison-Wesley Publishing Company

Waziri, D. 2018. Personal interview with Major General Dawlat Waziri, former Spokesperson of the Ministry of Defense Afghanistan \& Author of the Book: History of Afghanistan's Military Forces (Pashto). 10 August 2018.

Zakaria, F. 2015. "The key to solving the puzzle of Afghanistan is Pakistan." Washington Post. 8 October 2015. [online]. [cit. 11. 3. 2019]. Available at: https://www.washingtonpost.com/opinions/the-key-tosolving-the-puzzle-of-afghanistan/2015/10/08/1ebfa63a-6df1-11e5aa5bf78a98956699_story.html?utm_term=.9e15a9c8b5cd

Zakheim, D.S. 2011. A Vulcan's Tale: How the Bush Administration Mismanaged the Reconstruction of Afghanistan. Washington, D.C.: Brookings Institution Press.

Zaland, F.M. 2018. Personal interview with Faiz Muhammad Zaland, Assistant Professor of Governance \& Public Administration at Kabul University. 14 August 2018.

Zimmermann, M. 2010. “Zwischen privatem Interesse und Staat. Warlords in der Antike.” In: S. Förster, C. Jansen and G. Kronenbitter (eds.). Rückkehr der Condottieri? Krieg und Militär zwischen staatlichen Monopol und Privatisierung: Von der Antike bis zur Gegenwart. Paderborn/Munich/Vienna: Ferdinand Schöningh Verlag, 28-42.

Zmaray, Z. 2018. Personal Interview with Zabihullah Zmaray, the Vice Chairman of Provincial Council of Afghanistan's eastern Nangrahar province. 22 August 2018. 